\title{
THE EFFECT OF CBT NATIONAL EXAMINATION ON SENIOR HIGH SCHOOL STUDENTS' COGNITIVE READINESS AND ANXIETY FACING MATHEMATICS TESTS IN DIY PROVINCE
}

\author{
Eny Sulistyaningsih $^{1} *$, S. Sugiman ${ }^{2}$ \\ ${ }^{12}$ Department of Mathematics Education, Universitas Negeri Yogyakarta. Colombo Street No. 1, \\ Karangmalang, Yogyakarta 55821, Indonesia \\ * Coressponding Author. Email: enylistya@gmail.com, Telp: +6289665651657 \\ Received: $13^{\text {th }}$ September 2016; Revised: $3^{\text {th }}$ November 2016; Accepted: $3^{\text {rd }}$ November 2016
}

\begin{abstract}
The purpose of this study was to determine the influence of CBT and PBT national examination on students' cognitive readiness and anxiety facing mathematics national examination in DIY province, the influence of subject on students' cognitive readiness and anxiety facing mathematics national examination in DIY Province, and the interaction between national examination and major. This research was descriptive explorative ex-post facto. The population was all of natural and social science high school students in grade XII in DIY province. The number of sample was 654 students The results showed that the national examination influenced students' cognitive readiness and anxiety facing national examination. CBT and PBT national examination did not influence the cognitive readiness facing national examination. Both types of national examination influenced the students' anxietywith the average score of the students' anxiety facing CBT national exam higher than that of the students' anxiety facing PBT national examination. There was no effect caused by the differences of majors in terms of cognitive readiness and national examination math anxiety; and there was no interaction between the different types of national examinations and majors.
\end{abstract}

Keywords: national examination, CBT, PBT, cognitive readiness, anxiety

How to Cite: Sulistyaningsih, E., \& Sugiman, S. (2016). The effect of CBT national examination policy in terms of senior high school students' cognitive readiness and anxiety facing mathematics tests in DIY Province. Jurnal Riset Pendidikan Matematika, 3(2), 198-208. doi:http://dx.doi.org/10.21831/jrpm.v3i2.10868

Permalink/DOI: http://dx.doi.org/10.21831/jrpm.v3i2.10868

\section{INTRODUCTION}

Ministrial regulation number 20, 2003 states that education is a conscious and deliberate effort to create an atmosphere of learning and the learning process so that learners are actively developing the potential to have the spiritual power of religion, self-control, personality, intelligence, character, and skills needed by society, nation and state. One of the implementation processes of education is learning process that requires efforts from every individual concerned, such as teachers, students, and others to get a better life.

The success of the learning process can be seen from the implementation of the objectives achieved. Nitko (2011, p.20), a specific goal is the achievement of students from the implementation of the learning process. In addition, Bichi \& Moses (2015, p.290), state that assessment has an important role in the educational process and it is considered as an important measurement tool in evaluating student performance. The achievement of lesson objectives can be determined through measurement or assessment done by the teacher, the school, or the government. Moreover, Ebbut \& Straker (Marsigit, 2003, pp.5-6), clarify that the evaluation phase is the final stage of a learning process. One measurement made by the government to determine the extent of competence achieved by students is national examination (UN). The national examination is the measurement and assessment of the national competency achievement in specific subjects (Mendikbud 5, 2015, p.3). One of the subjects in the national examination at each level of education is Mathematics. Mathematics national examination aims at measuring the ability of Mathematics from the 
first to the last year at each level of education. Based on the Permendikbud number 5 (2015, p.9), national examination in the academic year 2014/2015 on junior and senior high school are conducted in two types, namely Paper-Based Test (PBT) and/or Computer-Based Test (CBT).

PBT national examination system is also called Pencil and Paper Test (PPT). It is because PBT requires pencils and papers in doing national examination. One of constraint on the PBT is the paper distribution especially to remote areas in Indonesia. However, in 2014/ 2015 national examination, it can be solved on time to the destination. There are some advantages of PBT national examination system so it is still used. One of the advantages of PBT national examination system is in the process of implementation. Students can perform the examination in an easy way because it allows students to do the examination without any special preparation. Bennett (2003, p.4), states that examination or lab tests with PBT systems for certain classes generate learning outcomes higher than to other systems, especially in reading and mathematics examination. In addition, the infrastructure used in PBT is simpler because its implementation does not require a lot of devices for preparation and costs for the development of facilities and infrastructure. AlAmri (2007, p.107), states that the PBT national examination system is more convenient, comfortable, and already accustomed.

The latest national examination systems adopted in Indonesia is the CBT.The use of CBT national examination for schools in Indonesia started in 2014/2015. In the early stage, the CBT national examination system in Yogyakarta Province was followed by 35 schools 34 of which are vocational schools. The CBT examination system, under consideration, will be processed gradually to other schools that have registered to the Department of Education, Youth and Sports (Dikpora) in each area. In 2015/2016, the number of schools implementing CBT national examination was increase, especially in DIY. With only one high school implementing CBT national examination in $2014 / 2015$ in the province, 32 high schools implemented CBT national examination in the following year.

One advantage of the CBT system according to Anies Baswedan is that there are three sessions with only one subject a day so the result are maintained. In addition, Temitayo, Adebisi, \& Alice (2013, p.336), clarify that CBT system is an effective solution for carrying out the evaluation or educational assessment for many students. In addition, Thurlow, Lazarus, Albus, et al. (2010, pp.22-28) state that it is possible if the lack of computers and supporting infrastructure will cause anxiety among students since they are not accustomed to use those. CBT national exam system is done in three sessions in a day. The consequence is that the third sessions will be done in the afternoon at 2:0004:00 p.m. Another consequence is that the implementation CBT national examination system is longer than the PBT national examination system can accomodate two subjects in one day.

The national examination is conducted in every year andit requires the readiness of both students and schools. Schools implementing CBT national examination should prepare a sufficient number of computers or the number of the examinees, the Internet network, the bandwidth capacity of at least 1 Mbps, Uninterruptable Power Supply (UPS), and two technicians. Schools implementing PBT national examination system should prepare national examination documents for the students. Readiness is important especially for students in class XII. It is because students will face national examination. Based on the results of a research conducted by Rumasoreng \& Sugiman (2014, p.27), 58.95\% of students in Central Maluku give wrong answer in Mathematics national examination. It shows that readiness is very needed to face mathematics national examination.

Mathematics national examination in senior high school level is adjusted to majors chosen by students. The majors are natural science, social science, and language major. However, in general, most of senior high school offers natural and social science major. The curriculum changed to curriculum 2013 affects changes of national examination indicators, especially Mathematics. The indiocator refer to a slice of both curriculum. Therefore, it takes more preparation to do national examination succesfully.

Burns (2004, p.119), state that the success of the exam is influenced by students' activities during preparations and their knowledge. Therefore, the students hope the result will be in line with their knowledge and readiness. For participants of the CBT national examination system, the government has offered a http://minites.puspendik.org/ online application to practice the national examination. Harjanto 
(2000, p.64), clarify that readiness is defined as a willingness to determine what type of actions as a result of it being received. Moreover, Hamalik (2005, P.39), states that readiness is a result of training or learning and maturity. The results of students' learning or maturity in national examination can be seen from students' cognitive readiness. Cognitive readiness level can be known by providing cognitive readiness test. It is called "try out" of national examination.

There are students who feel anxiety although the process of improving students' cognitive readiness has been done by them who will face national examination. Mardapi (2012: pp.6-7), state that national examination has both positive and negative effects. One of the negative impacts is an anxiety increase of teachers and students. Anxiety in certain limits is needed as students' motivation to learn better, but too high level of anxiety can lead students to become stressfull. Woolfolk, Anita, and Loraine (1984, p.301), state that situation in schools which mostly cause students' high level of anxiety are test or examination. It is because the result of a national examination is considered to be an important factor to determine the next level of education that will be faced by students.

The level of anxiety faced by students in national examination is different from one to another. Dobson (2012, p.4), different students will have a different anxiety response to face a situation. In addition, Woolfolk, Anita, and Loraine (1984, p.298), students' anxiety is caused by unsuccessful tasks done by them. Students' anxiety in facing a national examination can be caused by high expectations of the results of national examinations.

Based on this background, it is necessary to investigate the effects of CBT national examination system for students' cognitive readiness and anxiety in facing mathematics national examination in Yogyakarta Province. The purpose of the study is to determine the influences of the CBT and PBT national examination systems for students' cognitive readiness and anxiety in facing mathematics national examination in Yogyakarta Province, to determine the effects of taking major in natural and social science for cognitive readiness and anxiety in facing mathematics national examination in Yogyakarta Province, and to investigate the relations between national examination systems and the majors taken.

\section{METHODS}

This research is a descriptive exploratory study with an ex-post facto method. The research was conducted to students grade XII in the academic year of 2015/2016 in 7 schools that implemented the PBT national examination system and 7 schools that employed the CBT national examination system in Yogyakarta Province. The study started on February 17th, 2016 until March 5th, 2016.

\section{Population and Sample}

The population in this study was all students of class XII from high schools in Yogyakarta in the academic year of 2015/2016. Sampling techniques in this study werea combination of stratified random sampling, purposive random sampling, and cluster random sampling. The population is stratified by regions and cities. Furthermore, each district and city were grouped by national examination score categories based on the government regulation number 5 in 2015 as shown in Table 1.

Table 1. Score Category of National Examination

\begin{tabular}{cl}
\hline Range & Category \\
\hline $100 \geq X>85$ & very good \\
$85 \geq X>70$ & good \\
$70 \geq X>55$ & medium \\
$X \leq 85$ & less \\
\hline
\end{tabular}

The population in each regency and city was regrouped using cluster random sampling technique based on considerations on schools implementing the CBT national examination system and the PBT national examination system. The next sampling technique used was purposive random sampling. It was to determine the schools selected as samples of each regency and city with considerations on the category of UN values and national examination system used. The number of schools selected as samples in each regency and city implementing CBT national examination were the same with schools implementing PBT national examination. However, there were not samples in medium category. Consequently, the medium category sampling was done by using the whole schools in Yogyakarta Province which are in moderate levels. Based on the school selected, there were classes randomized in both majors (natural and social science) so that a natural and social science were choosen from each school. There were 16583 population. Based on Krejcie and Morgan's table, the number of minimum 
sample will be 376 students. This study used 654 students as samples.

\section{Research Variables}

The variables in this study consist of independent variables that is government policy on the CBT and PBT national examination system, and high school students who take natural and social science major. The dependent variables of this study consist of students' cognitive readiness and anxiety in facing mathematics national examination in Yogyakarta Province.

\section{Instruments and Data Collection Techniques}

The study was conducted before the national examination was held. The students did multiple choice test instruments to measure mathematics cognitive readiness. The test had been adapted by indicators of mathematics national examination in 2015/2016. In addition, the samples were also given a questionnaire to measure students' anxiety in facing mathematics national exams using either CBT or PBT system. Time allocation was 120 minutes.

The next step in this research was analyzing data from the results of students' cognitive readiness and anxiety test statistically. It was to determine effects of CBT national examination system for students' cognitive readiness and anxiety in facing mathematics national examination in Yogyakarta Province.

\section{Validity and Reliability Instruments}

This study used content and construct validity. Content validity was used to prove the validity of test instruments. It was suited with indicators of mathematics national examination in 2015/2016. Content validity was also used to prove the validity of the anxiety questionnaire. Construct validity was used to prove the validity of the questionnaires. Construct validity used factor analysis.

Results of construct validity for the anxiety questionnaire instrument shows that KMO's value is 0.720 . It is more than 0.5 which means that samples used in the study are sufficient. In addition, from the analysis, it is shown that there are 9 factors obtained from the total factors. The number represents $67.14 \%$ of the variabels.

The construct validity result of the anxiety in facing PBT national examination system questionnaire is 0.660 . It is more than 0.5 which means that the number of samples used in the study is sufficient. In addition, from the analysis, it is shown that there are 9 factors obtained from the total factors. The number represents $66.54 \%$ of the variabels.

Estimated reliability of the cognitive readiness instrument used was KR-20. It is because the instrument used multiple choice formats. Estimated reliability of students' anxiety used was internal consistency reliability shown by Cronbach alpha coefficient.

The reliability test estimation result of cognitive readiness in natural science major was calculated using the KR-20. It is 0.681 and the SEM score is 1.563 . The reliability test estimation result of cognitive readiness in social science major was also calculated using the KR20. It is 0.706 and the SEM score is 2.73 . The results of the analysis of the anxiety reliability estimation in facing examination using CBT questionaire is 0.824 to 5.59 in SEM values. The reliability estimation results of the anxiety in facing PBT national examination questionaire is 0,800 and the SEM score is 5.88 .

\section{Data Analysis Techniques}

A descriptive analysis was conducted to obtain data descriptions of students' cognitive readiness and anxiety in facing CBT and PBT national examination. Descriptive analysis was presented in the average, median, mode, standard deviation, and the maximum and minimum score of each data. The next analysis was equalization. The purpose of this analysis is to produce scores that are interchangeable (Retnawati, 2014, p.93). It used horizontal equalization with equivalent group design. Equalization method was based on the classical theory using equipercentile method. Percentile metric scores on two tests were matched according to the same percentile (Dragon, 1992, p.358).

The analysis was followed by hypothesis testing. Hypothesis testing was done by using two-ways MANOVA. However, before the hypothesis test, there were previous assumption tests of normality and homogeneity. Prerequisite test was used to test the normality of the data by looking at the samples. Multivariate normality test used Mahalanobis distance test.

$$
d_{j}^{2}=\left(\boldsymbol{x}_{j}-\overline{\boldsymbol{x}}\right)^{\prime} \boldsymbol{S}^{-1}\left(\boldsymbol{x}_{j}-\overline{\boldsymbol{x}}\right)
$$

$d_{j}^{2}:$ Mahalonobis distance

$x_{j}: \mathrm{j}^{\text {th }}$-data, $\mathrm{j}=1,2, \ldots, \mathrm{n}$ 
$\bar{x}:$ Average of data

$S^{-1}$ : Inverse matrix of covariates

A decision criterion is if the correlation coefficient is more than $r$ table or sig. less than 0.5 , it means that there is a significant correlation or normal distribution of data.

The second assumption used was homogeneity test. Homogeneity test aims to determine the variety of the population. It is shown by looking at the matrix covariance of cognitive readiness and anxiety in facing CBT and PBT national examination scores. Multivariate homogeneity test used was Box's $\mathbf{M}$ test. A decision criterion is if the significant value is more than 0.05 then the data is homogeneous.

Hypothesis testing used was two-ways MANOVA analysis. The first hypothesis test was to determine implementation effects of CBT and PBT national examination system for students' cognitive readiness and anxiety in facing mathematics national examination in Yogyakarta Province. Hypothesis:

$H_{0}:\left(\begin{array}{l}\mu_{11} \\ \mu_{21}\end{array}\right)=\left(\begin{array}{l}\mu_{12} \\ \mu_{22}\end{array}\right)$

(There was no influence of national examination system (CBT and PBT) for students' cognitive readiness and anxiety in facing mathematics national examination Yogyakarta Province)

$H_{1}:\left(\begin{array}{l}\mu_{11} \\ \mu_{21}\end{array}\right) \neq\left(\begin{array}{l}\mu_{12} \\ \mu_{22}\end{array}\right)$

(There was influence of national examination system (CBT and PBT) for students' cognitive readiness and anxiety in facing mathematics national examination Yogyakarta Province)

The second hypothesis was to determine influences of the majors (natural and social science) for students' cognitive readiness and anxiety in facing mathematics national examination in Yogyakarta Province. Hypothesis:

$$
H_{0}:\left(\begin{array}{l}
\mu_{11} \\
\mu_{12}
\end{array}\right)=\left(\begin{array}{l}
\mu_{21} \\
\mu_{22}
\end{array}\right)
$$

(There was no effect of majors on the students' cognitive readiness and anxiety facing mathematics national examination in Yogyakarta Province)

$H_{1}:\left(\begin{array}{l}\mu_{11} \\ \mu_{12}\end{array}\right) \neq\left(\begin{array}{l}\mu_{21} \\ \mu_{22}\end{array}\right)$

(There was effect of majors on the students' cognitive readiness and anxiety facing mathe- matics national examination in Yogyakarta Province).

The third hypothesis test was to determine relations between the national examination system and majors. Hypothesis:

$$
H_{0}: \mu_{11}-\mu_{21}-\mu_{12}+\mu_{22}=0
$$

(There were no interaction between national examination system and majors).

$H_{1}: \mu_{11}-\mu_{21}-\mu_{12}+\mu_{22} \neq 0$

(There were no interaction between national examination system and majors).

$\mu_{11}$ : An average score of students who did the CBT national examination system on natural science major.

$\mu_{21}$ : Students' average score of students who did the CBT national examination system on social science major.

$\mu_{12}$ : Students' average score of students who did the PBT national examination system on natural science major.

$\mu_{22}$ : Students' average score of students who did the PBT national examination system on social science major.

If the hypothesis test showed that there is an influence of the national examination system for students' cognitive readiness and anxiety in facing mathematics national examination in Yogyakarta Province, it is continued by looking at tables Test of Between-Subject Effects to determine the differences between variables.

\section{RESULTS AND DISCUSSIONS}

The data description of cognitive readiness of students facing CBT national examination is presented in Table 2 .

Table 2. Description of Students' Cognitive Readiness in Facing CBT National Examination

\begin{tabular}{llll}
\hline & $\begin{array}{c}\text { Natural } \\
\text { Science }\end{array}$ & $\begin{array}{c}\text { Social } \\
\text { Science }\end{array}$ & Total \\
\hline Number of students & 167 & 151 & 318 \\
Average & 20,467 & 20,617 & 20,54 \\
Median & 19 & 19 & 19 \\
Modus & 15 & 19 & 19 \\
Standard Deviation & 6,164 & 5,909 & 6,046 \\
Maximum Score & 35 & 32 & 35 \\
Minimum Score & 10 & 10 & 10 \\
\hline
\end{tabular}

Table 2 shows that the students' cognitive readiness in facing CBT national examination. Natural science students' average score of cognitive readiness is lower (20.467) than social science students (20.617), while the overall 
average score is 20.54 . Both natural and social science students have the same median score which is 19 . The mode score of natural science students is lower than social science students'. The natural science students' mode score is 15 and the social science students' is 19. It is the same mode score overall. Standard deviation scores of natural science students is higher (6.164) that social science (5.909). Both groups have the same minimum score that is 10 but they have different maximum score. Natural science students have 35 as the maximum score while the maximum score of social science is 32 . Actually, the overall maximum score is 40 . It implies that the range scores of cognitive readiness in facing CBT national examination is 10-35 and overall score range is $0-40$.

The data description of cognitive readiness of students facing PBT national examination is presented in Table 3.

Table 3. Description of Students' Cognitive Readiness in Facing PBT National Examination

\begin{tabular}{llll}
\hline & $\begin{array}{c}\text { Natural } \\
\text { Science }\end{array}$ & $\begin{array}{c}\text { Social } \\
\text { Science }\end{array}$ & Total \\
\hline Number of students & 174 & 162 & 336 \\
Average & 19,414 & 19,721 & 19,56 \\
Median & 20 & 21 & 20 \\
Modus & 24 & 17 & 24 \\
Standard Deviation & 5,649 & 4,737 & 5,255 \\
Maximum Score & 35 & 31 & 35 \\
Minimum Score & 10 & 10 & 10 \\
\hline
\end{tabular}

Table 3 shows that the study conducted to 174 students majoring natural science and 162 students majoring social science. Natural science students' average score of cognitive readiness is lower (19.414) than social science students (19.721), while the overall average score is 19.56. Median score of students majoring natural science is same with overall median score that is 20. But it is lower than students majoring social science median score that is 21. However, the students majoring natural science mode scores that is same as the overall mode score (24) is higher than students majorng social science mode score that is 17 . Students majoring natural science standard deviation score is also higher than social science. Although the students majoring natural science have higher maximum score (35) than social science (31), but the minimum score of the two majors are same that was 10. It implies that the range score of cognitive readiness in facing PBT national examination is same with the range scores of cognitive readiness in facing CBT national examination that was $10-35$.
The data description of students' anxiety in facing CBT mathematics national examination is presented in Table 4 .

Table 4. Data of Students' Anxiety in Facing CBT Mathematics National Examination

\begin{tabular}{llll}
\hline & $\begin{array}{l}\text { Natural } \\
\text { Science }\end{array}$ & $\begin{array}{l}\text { Social } \\
\text { Science }\end{array}$ & Total \\
\hline Number of students & 167 & 151 & 318 \\
Average & 86,521 & 84,09 & 85,3 \\
Median & 88 & 84 & 87 \\
Modus & 88 and 89 & 83 & 88 \\
Standard Deviation & 12,584 & 12,90 & 12,7 \\
Maximum Score & 118 & 115 & 118 \\
Minimum Score & 48 & 45 & 45 \\
\hline
\end{tabular}

Table 4 shows that the study conducted to 167 students majoring natural science and 151 students majoring social science facing CBT national examination. Natural science students' average score of anxiety is higher (86.521) than social science students (84.099). It states that natural science students feel more anxious than the other group. Natural science students' median score of anxiety is also higher (88) than social science (84). It is also higher than the overall median score. Natural science students' mode score of anxiety facing CBT national examination is also higher at 88 and 89 than social at 83. Standard deviation score of natural science students is 12.584 and social science is 12.907. Maximum and minimum anxiety score of natural science student is also higher than social science, maximum is 118 and minimum is 48 , than social science that has maximum score is 115 and minimum score is 45 . It implies that the overall range anxiety scores facing CBT national examination is $45-118$.

The data description of students' anxiety in facing PBT mathematics national examination presented in Table 5.

Table 5. Data of Students' Anxiety in Facing PBT Mathematics National Examination

\begin{tabular}{llll}
\hline & $\begin{array}{c}\text { Natural } \\
\text { Science }\end{array}$ & $\begin{array}{c}\text { Social } \\
\text { Science }\end{array}$ & Total \\
\hline Number of students & 174 & 162 & 336 \\
Average & 82,121 & 79,451 & 80,833 \\
Median & 83 & 80 & 81,5 \\
Modus & 85 & 85 & 85 \\
Standard Deviation & 13,691 & 12,425 & 13,144 \\
Maximum Score & 114 & 109 & 114 \\
\hline
\end{tabular}




\begin{tabular}{llll}
\hline Minimum Score & 40 & 48 & 40 \\
\hline
\end{tabular}

Table 5 shows that the study conducted to 174 students majoring natural science and 162 students majoring social science facing PBT national examination. Natural science students' average score of anxiety facing national examination is higher (82.121) than social science students that students' average scores is 79.451 . While the overall average score is 80.833 . Natural science students' median score is also higher at 83 then social science that are 80 . Overall median score is 80.833 . Natural science, social science, and overall mode score is same that is 85 . The standard deviation of natural science students is higher (13.691) than social science that is 12.425 . Maximum score of natural science students (114) is higher than social science (109). Meanwhile, minimum score of natural science student facing PBT national examination is lower (40) than social science students (48). It implies that overall range anxiety scores facing PBT national examination is $40-118$.

The anxiety criteria of each student in facing national examination are different. Students' anxiety criteria in facing CBT and PBT national examination systems are categorized in Table 6.

Table 6. Categorization of Students' Anxiety

\begin{tabular}{cc}
\hline Category & Criteria \\
\hline $120<X \leq 150$ & very high \\
$100<X \leq 120$ & High \\
$80<X \leq 100$ & Moderate \\
$60<X \leq 80$ & Low \\
$30<X \leq 60$ & very low \\
\hline
\end{tabular}

Based on a range of anxiety criteria in Table 6, it explains that the average score of natural science students' anxiety in facing CBT national examination is 86.521 while the average score of social science students' anxiety is 84.99. The both of them categorized into moderate. Overall, the average score of students' anxiety in facing CBT national examination (85.371) is categorized into a moderate criterion. The average score of natural science students' anxiety in facing PBT national examination system (82.121) is categorized into a moderate criterion. The average score of social science (79.451) is categorized into a low criterion. However, overall average scores of students' anxiety in facing PBT national examination system (80.833) are categorized into a moderate criterion.
The students' anxiety levels in facing national examination are presented in chart.

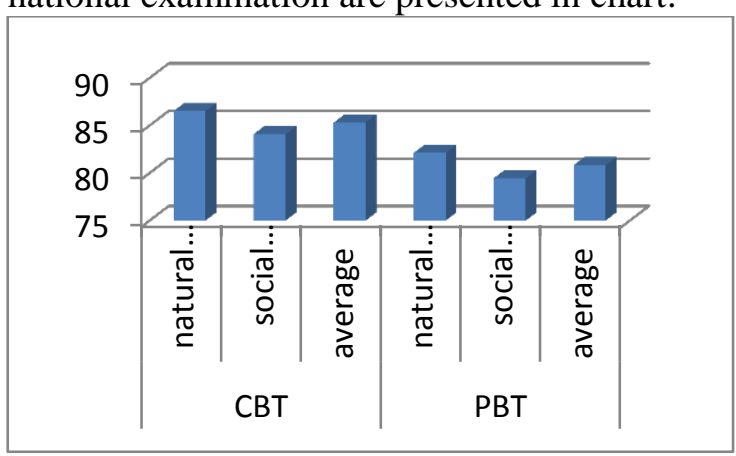

Chart 1 . The level of students' anxiety facing national examination

Chart 1 shows that the highest students' anxiety facing CBT national examination belongs to natural science students while the lowest belongs to social science students. In addition, it demonstrates that the average score of students' anxiety in facing CBT national examination is higher than those facing PBT.

The hypothesis analysis was further examined by using two-ways Manova. Previously, prerequisite tests consisting of normality and homogeneity tests must be done. The normality test is used to determine whether the data obtained is a normal distribution or not. Mahalanobis distance analysis used SPSS application. It used a correlation between Mahalanobis distance and $\chi_{p}^{2}\left(\frac{j-0,5}{n}\right)$ value. It is presented in Table 7.

Table 7. Analysis Result of Mahalanobis Distance

\begin{tabular}{ccccc}
\hline $\begin{array}{c}\text { Sample } \\
\text { group }\end{array}$ & Sign. & Correlation & $\mathbf{r}_{\text {table }}$ & Result \\
\hline CBT & 0,000 & 0,993 & 0,1519 & normal \\
PBT & 0,000 & 0,982 & 0,1488 & normal \\
\hline
\end{tabular}

According to Table 7, it is shown that the normality test conducted to a sample group of students implementing the CBT national examination has 0.00 significance values. It is less than 0.05 so that there is a significant correlation. In other word, the data have a multivariate normal distribution. Moreover, the correlation value 0.993 which is higher than r-table = 0.1519 states that data is normal. Students impelementing PBT national examination has normality test score 0.000 which is less than 0.05 . It shows that there is a significant correlation or the data have a multivariate normal distribution. 


\section{Jurnal Riset Pendidikan Matematika, 3 (2), November 2016 - 205}

Eny Sulistyaningsih, S. Sugiman

The prerequisite test aims to determine the homogeneity of variance of the population. Based on the multivariate calculation, it is known that the significance level is 0.051 orhigher than 0.05 . It means that the data is homogeneous. In other word, the covariance matrix score of students facing CBT national examination system is the same with students facing PBT national examination system.

The first hypothesis test is to answer the problem formulation whether the CBT and PBT national examination system significantly influence students' cognitive readiness and anxiety in facing mathematics national examination in Yogyakarta Province. Based on the analysis, the significance value is 0,001 . It is less than 0.05 so that $\mathrm{H} 0$ was rejected. It means that there is a significant influence of national examination systems on the students' cognitive readiness and anxiety.

The second hypothesis test is to answer the problem whether the majors taken affect students' cognitive readiness and anxiety in facing national examination. Manova test results show 0.691 significance value, higherthan 0.05 so that $\mathrm{H} 0$ was accepted. It states that there is no influence caused by different majors for students' cognitive readiness and anxiety. Some natural or social science students faced CBT national examination and others faced PBT national examination system. There is no significant difference in anxiety level among them. Moreover, sense of inadequacy was also felt by students in both majors. Each of the students had personal goals that must be achieved on the national examination. It triggered students' anxiety that appeared on each student's self.

The third hypothesis test is used to answer the problem formulation whether there are relations between the national examination systems and the majors. The score earned from multivariate analysis is 0.914 . It is more than 0.05 so that $\mathrm{H} 0$ is accepted. It means that there is no relation between national examination systems and majors. In natural and social science major, there were different Mathematics materials. Besides, the majors got the same treatment from school to improve student's cognitive readiness. National examination indicators were different between both of majors. Consequently, each student from both majors tried to get the best results in national examination. In other words, the difference of national examination system did not influence if it was given to natural or social science students. It is because both national examination and the majors are different.

Based on the first hypothesis analysis, there are significant influences of national examination system for students' cognitive readiness and anxiety in facing mathematics national examination. The next step used Table Test of Between-Subject Effects of two-ways Manova analysis. The result states that significant value of students' cognitive readiness is 0.590 . It was more than 0.05 . It means that the national examination systems have no influence on students' cognitive readiness. It is because of all students who both types of national examination systems should prepared their cognitive readiness in facing national examination using the same indicators. The schools with both national examination systems provided more exercises and students understood about the subjects in national examination. This analysis is also supported by Retnawati $(2015, p .135)$ that in general CBT and PBT are relatively similar in terms of the measurement of the ability of TOEP. In addition, these result are also consistent with the result of Piaw research (Piaw, 2012 , p. 655) that the scores of pre-test and posttest on biology lesson are consistent between Paper-Based Testing and Computer-Based Testing.

Furthermore, the results of Table Test of Between-Subject Effects are used to determine whether national examination systems influence students' anxiety in facing national examination. The analysis shows 0.00 as significant value which is less than 0.05 so that $\mathrm{HO}$ is rejected. It means that there are significant influences of national examination systems for students' anxiety in facing national examination. Students' anxiety will increase when students should face new kind of national test examination systems such as CBT. The new thing for students will give effects to their anxiety. Some students who are already accustomed to using computers will have lower anxiety in facing CBT national examination than those who are not familiar with computers in daily life. Besides, the anxiety level of students who did the PBT national examination system also increase. It is because of fear or worry about the results of national examination. It is in line with Wolfolk, Anita, and Loraine's theory (1984, p.298) that students who are not able to complete a task is often filled with anxiety. This finding supports Taylor's theory (Leonard \& Supardi U.S., 2010, p. 342) that anxiety is the effect of the inability 
of the individual in dealing with problems. However, anxiety of the students can be minimalized with the roles of the teacher. Dobson (2012, p.5) states that if the teacher is able to recognize the signs of students' anxiety, it will assist students in overcoming their anxiety. Teachers should understand different methods in overcoming students' anxiety.

The next analysis was independent sample t-test. It was done if national examination influences students' anxiety. This analysis aims to determine the differences of anxiety average score between students facing CBT and PBT national examination.

Based on the analysis, the $t_{\text {value }}$ obtained is 4.47. It is more than $t_{\text {table }}=1.963$. It means that the average score of the students' anxiety in facing CBT national examination is not equal to the average score of the students' anxiety in facing PBT national examination. Based on students' anxiety average score, it proves that the average score of students who did CBT national examination is higher (85.371) than another (80.833). It means that the anxiety level of students who did the CBT national examination is higher and significantly different compared to another.

The next data analysis was to know the correlation between students' cognitive readiness and anxiety in facing national examination. Based on the analysis, the significance value is 0.016. It is less than 0.05 , which means that there is a significant relation between students' cognitive readiness and anxiety. The value correlation is -0.94 . It means that there is a very strong relation between the students' cognitive readiness and anxiety in facing national examination and vice-versa. If the students' anxiety level is high then the students get low cognitive readiness, and vice-versa. Agustiar \& Asmi (2010, p. 13) clarify that the students who have high anxiety also tend to worry, anxious, and difficult to concentrate when they face a threatening situation as well as the national examination. Students who have low anxiety tend to be aware of situations such as national examination so that they can anticipate the situation. Dobson (2012, p.26) states that students who have more time preparing the examination will have lower anxiety than others.

The last data analysis was to make an equalization data of students' anxiety in facing national examination systems. It was done because the measurement of students' anxiety was done by different instruments although the indicators were the same. The result aims to produce a score that can replace each other if only one of anxiety test instruments used. Graph 2 shows Middle Percentile Ranking result of students' anxiety scores in facing national examination systems.

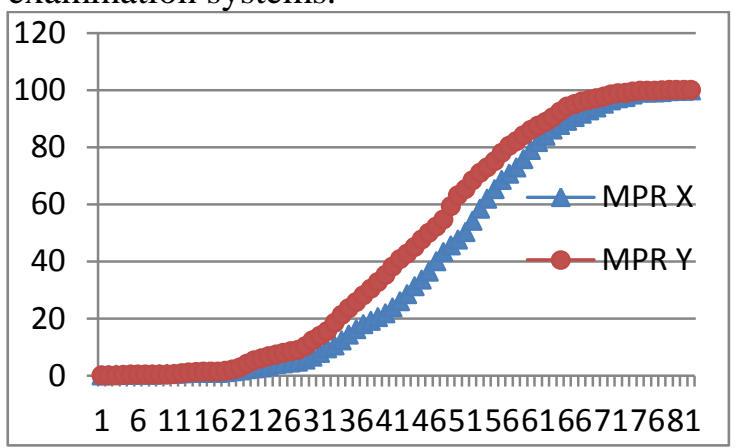

\section{Graph 2. Graph of Middle Percentile Ranking result of students' anxiety scores in facing national examination systems.}

MPR X: Middle Percentile Ranking (MPR) of students' anxiety scores in facing CBT national examination.

MPR Y: Middle Percentile Ranking (MPR) of students' anxiety scores in facing PBT national examination.

Graph 1 shows that at a certain percentile, anxiety instruments in facing CBT national examination give students higher anxiety scores than anxiety instruments in facing PBT national examination. The next step was converting scores of students' anxiety in facing PBT national examination to students' anxiety score in facing CBT national examination. Converted score is range scores that exist in the both data of students' anxiety in facing CBT and PBT national examination systems.

\section{CONCLUSIONS}

Based on the results of the discussion, it can be concluded that there are significant influences of CBT and PBT CBT and PBT national examination system for students' cognitive readiness and anxiety in facing mathematics national examination. However, the national examination system has no effect for students' cognitive readiness. It only influences students' anxiety in mathematics national examination. In addition, the average scores of the students' anxiety in facing CBT national examination systems are different from those who do PBT national examination system. The majors taken have no influence for students' cognitive readiness and anxiety in facing 


\section{Jurnal Riset Pendidikan Matematika, 3 (2), November 2016 - 207}

Eny Sulistyaningsih, S. Sugiman

mathematics national examination. There is no interaction between the national examination system and the majors.

Based on these results, further research is expected to expand the coverage area and add a dependent variable in order to get an overview of the results of a broader research and include more aspects.

\section{REFERENCES}

Agustiar, W., \& Asmi, Y. (2010). Kecemasan menghadapi ujian nasional dan motivasi belajar pada siswa kelas XII SMA Negeri “ X " Jakarta Selatan. Jurnal Psikologi, 8(1), 9-15. Retrieved from http://www.ejurnal.com/2013/09/kecemasanmenghadapi-ujian-nasional-dan_29.html

Al-Amri, S. (2007). Computer-based vs. paperbased testing: Does the test administration mode matter? Proceedings of the BAAL Conference 2007 pg 101-110.

Bennet, R.E. (2003). Online assessment and the comparability of score meaning. Research Memorandum RM-03-05.

Bichi, A.A., \& Musa, A. (2015). Assessing the correlation between continuous assessment and examination scores of education courses. American international journal of research in humanities, arts and social sciences page 290-294.

Burns, D.J. (2004). Anxiety at the time of final exam: Relationships with expectations and performance. Journal of Education for Bussiness page 119-124.

Dobson, C. (2012). Effect of academic anxiety on the performance of students with and without learning disabilities and how students can cope with anxiety at school. Thesis, not printed, Northern Michigan University, Michigan.

Hamalik, O. (2005). Perencanaan pengajaran berdasarkan pendekatan sistem. Jakarta: Bumi Aksara.

Harjanto. (2000). Perencanaan pengajaran. Jakarta: Rineka Cipta.

Leonard, \& Supardi U.S. (2010). Pengaruh konsep diri, sikap siswa pada matematika, dan kecemasan siswa terhadap hasil belajar matematika. Cakrawala Pendidikan, 29(3), 341-352. Retrieved from http://journal.uny.ac.id/index.php/cp/article /view/362

Mardapi, D. (2012). Dampak ujian nasional pada karakter bangsa. Presented at national seminar of Postgraduate program of Yogyakarta State University and Himpunan Evaluasi Pendidikan Indonesia (HEPI) 2012.

Marsigit. (2003). Metodologi pembelajaran matematika. Presented at elementary school teacher visited in Mathematics and Science Faculty of Yogyakarta State University.

Mendikbud. (2015). Peraturan menteri pendidikan dan kebudayaan Republik Indonesia nomor 5, tahun 2015 tentang kriteria kelulusan peserta didik, penyelenggaraan ujian nasional, dan penyelenggaraan ujian sekolah/madrasah/pendidikan kesetaraan pada SMP/MTS atau yang sederajat dan SMA/MA/SMK atau yang sederajat.

Naga, D.S. (1992). Pengantar teori sekor pada pengukuran pendidikan. Jakarta: Gunadarma.

Nitko, A.J., \& Brookhart. (2011). Educational assessment of student $\left(6^{\text {th }} \mathrm{ed}\right)$. Boston: Pearson.

Piaw, C. Y. (2012). Replacing paper-based testing with computer-based testing in assessment: Are we doing wrong? Procedia - Social and Behavioral Sciences, 64(0), 655-664. http://doi.org/10.1016/j.sbspro.2012.11.07 7

Republik Indonesia. (2003). Undang-Undang RI Nomor 20, Tahun 2003, tentang Sistem Pendidikan Nasional.

Retnawati, H. (2014). Teori respon butir dan penerapannya. Yogyakarta: Nuha Medika.

Retnawati, H. (2015). The comparison of accuracy scores on the paper and pencil testing vs. computer based testing. The Turkish Online Journal of Educational Technology-Oktober 2015 volume 14 issue 4, 135-142.

Rumasoreng, M., \& Sugiman, S. (2014). Analisis kesulitan matematika siswa SMA/MA dalam menyelesaikan soal setara UN di Kabupaten Maluku 
Jurnal Riset Pendidikan Matematika, 3 (2), November 2016 - 208

Eny Sulistyaningsih, S. Sugiman

Tengah. Jurnal Riset Pendidikan Matematika, 1(1), 22-34. Retrieved fromhttp://journal.uny.ac.id/index.php/jrp $\mathrm{m} /$ article/view/2661.
Woolfolk, A.E., \& Nicholich, L.M.. (1984). Educational psychology for teachers. $\left(2^{\text {nd }}\right.$ ed). New Jersey: Prentice Hall. Inc 